\title{
CALCULATING TRAGEDY: ASSESSING THE COSTS OF TERRORISM
}

\author{
Bruno S. Frey, Simon Luechinger and Alois Stutzer \\ University of Zurich
}

January 30, 2006

\begin{abstract}
The trends and consequences of terrorist activities are often captured by counting the number of incidents and casualties. More recently, the effects of terrorist acts on various aspects of the economy have been analyzed. These costs are surveyed and put in perspective. As economic consequences are only a part of the overall costs of terrorism, possible approaches for estimating the utility losses of the people affected are discussed. Results using the life satisfaction approach, in which individual utility is approximated by self-reported subjective well-being, suggest that people's utility losses may far exceed the purely economic consequences.
\end{abstract}

JEL classification: D74, H56, I31

Keywords: Terrorism, tourism, foreign direct investment, savings and consumption, stock market, national income, subjective well-being, life satisfaction

\footnotetext{
$\square$ Address: Institute for Empirical Research in Economics, University of Zurich, Bluemlisalpstr. 10, CH-8006 Zurich, Switzerland. Phone: +41-(0)44-634 37 31, fax: +41-(0)44-634 49 07, email: bsfrey@iew.unizh.ch, sluechinger@iew.unizh.ch and astutzer@iew.unizh.ch. The first and third authors are also associated with CREMA - Center for Research in Economics, Management and the Arts.
} 


\section{Introduction}

Most people take it for granted that terrorism is the major plague we are now dealing with in the $21^{\text {st }}$ century. On a number of occasions, terrorists succeeded in inflicting massive civilian casualties and colossal damage, as in the case of the attacks on the World Trade Towers in New York on September 11, 2001, the bombings aboard four commuter trains in Madrid on March 11, 2004, and the bombings on the London subway on July 7, 2005. Although, in connection with the proliferation of religious terrorism, the propensity for spectacular largescale attacks increased, terrorism is not restricted to Islamic militants in general and al Queda in particular. Rather, many countries were plagued by terrorist campaigns in the $20^{\text {th }}$ century. Fighters in anti-colonial struggles, ethnic separatist groups, revolutionary left-wing terrorists and their right-wing counterparts all tried to harm their opponents in order to force them to yield to their demands or overthrow them (see e.g. Hoffman, 1998; Wilkinson, 2000).

This paper focuses on the economic costs and overall consequences for society of terrorism. Terrorism can affect economic activity in four different ways. First, terrorist attacks derogate a country's capital stock, both human and physical capital. Examples of such direct destructions are the impacts of September 11, 2001, or the frequent attacks on oil pipelines. Second, terrorist campaigns divert foreign resources away from the affected countries to other destinations. Primary examples are the tourism industry and foreign direct investment. Third, terrorism induces higher level of uncertainty and, thereby, distorts the resource allocation within a country through changes in the individuals' savings, investment and consumption behaviour. Fourth, heightened security measures increase transaction costs and draw away resources from more productive use. Moreover, terrorist attacks evoke a climate of fear which reduces people's well-being beyond the immediate economic consequences. ${ }^{1}$

The central aim is to show that the various damages done by terrorism can be empirically measured. ${ }^{2}$ In recent years, economic scholars have analyzed the effects terrorist acts have on

\footnotetext{
${ }^{1}$ Terrorism can have serious effects on other aspects of society, such as on politics. Thus, the terrorist attack in Madrid on March 11, 2004 resulted in a sudden and substantial drop in the votes going to the reigning Partido Popular, so that it lost the election which it had looked virtually certain to win before. This loss has been largely attributed to the incompetent reaction on the part of the government to the attack (Financial Times 2004, p. 11). Studying the relationship between terrorist attacks in Israel and the occupied territories from 1990 and 2003 and electoral outcomes in Israel, Berrebi and Klor (2004) find that relative support for the rightist party increases after periods with high levels of terrorism and decreases after relatively calm periods.

${ }^{2}$ No general survey on the economic research on terrorism is provided in this paper; this has been done elsewhere. See e.g. Enders and Sandler (1995), Frey and Luechinger (2003) and Sandler and Enders (2004).
} 
different aspects of the economy and society. We briefly discuss how the extent of terrorism is measured and the most important trends in international terrorism (section 2). The following section assesses empirical studies on the impact of terrorism on tourism, foreign direct investment, savings and consumption, investments, stock markets, foreign trade, urbanization and overall economic development, including the costs of the attacks of September 11, 2001. ${ }^{3}$ Several estimates of the effects of terrorism will be given, but it is, of course, not possible to come up with one single figure for the economic damages caused by terrorism. Moreover, the overall effects of terrorism may well exceed the economic consequences. Therefore, possible approaches for estimating the utility losses of the population affected, as well as first results, are discussed in section 4. Section 5 offers concluding remarks.

\section{Counting terrorist acts and casualties}

Most studies assessing the tragedy of terrorism rely on indicators of terrorist activity. ${ }^{4}$ Some of the social science literature uses these measures directly to evaluate the harm suffered. Instead, in the research surveyed below, measures of terrorist activity are used as an input to calculate the various costs of terrorism to the economy. This section, therefore, briefly discusses how terrorist activity is captured in international statistics.

A frequently used indicator is the number of terrorist incidents. However, counting the number of terrorist incidents means that terrorist activities of widely varying magnitude are lumped together. The attacks on the World Trade Center would be counted as one (or perhaps two) event(s), the same as taking one person as a hostage. Such measurements can capture developments in terrorism only if the structure of terrorist events remains more or less unchanged. Thus, measuring the number of incidents makes sense if the percentage of hostage takings and major attacks remains approximately constant. The varying intensity of terrorist

\footnotetext{
${ }^{3}$ Related issues not discussed in this paper are the effects of terrorism on fiscal policy (see e.g. Gupta et al., 2004; Eichenbaum and Fisher, 2005) and the discussion about the insurability of terrorism risks (see e.g. Cummins and Lewis, 2003; Kunreuther, Michel-Kerjan and Porter, 2003; Brown, 2004). Precursors interested in the general interaction between war, peace and economic conditions are Pigou (1916; 1921), Keynes (1919) and Robbins (1940). More recent contributions, analyzing the interaction of conflict and economic activity, are Hess and Orphanides (1995; 2001), Garfinkel (1990; 1994), Grossman (1991) and Collier and Hoeffler (2004).

${ }^{4}$ Exceptions are Abadie and Gardeazabal (2003), who use a truce unilaterally declared by the ETA in the late 1990s as a natural experiment, and the studies focusing on the consequences of specific incidents, such as the September 11, 2001 attacks discussed in section 3.
} 
attacks is often captured by the number of casualties. Some data only use the number of persons killed, while other data also take into consideration the number of people injured.

Another problem is that only those terrorist events reflected in official statistics and reported in the media are counted. Reliance on official statistics is often mistaken, because either the authorities themselves do not know or deliberately bias their reporting. The media only pick up on some terrorist events, mostly those occurring in the larger cities or the capital of the country, where the foreign journalists normally reside. Terrorist action taking place in remote rural areas is rarely, if ever, reported in the media. The problem of biased reporting is especially severe in less developed and authoritarian countries (see e.g. Miller, 1994).

The problems associated with the limits of comparing different types of attacks and of biased reporting of attacks have been addressed in various ways in the literature. First, the analysis is usually confined to developed countries where the reporting bias is less of a problem. Second, the consequences are often estimated for a small number of countries, or even a single country, where modes of attack are comparable across countries and over time (exceptions are the combined cross-country and time-series analyses of Blomberg, Hess and Orphanides, 2004; Nitsch and Schumacher, 2004 discussed below). Third, some authors explicitly differentiate between attacks of different types and at different locations (see e.g. Drakos and Kutan, 2003; Fielding, 2003b).

In the case of international terrorism, where foreign interests are involved, the reporting bias is likely to be less severe. Employing the official US definition of terrorism (22 USC $\S$ $2656 \mathrm{f}[\mathrm{d}]$ ), the US Department of State issues series covering the annual number of incidents of international terrorism and the number of fatalities. International terrorism is defined as terrorism involving citizens or the territory of more than one country. These series are depicted in figure 1.

The number of terrorist events recorded in this statistic varies considerably from 125 in 1968 to 665 in $1987 .{ }^{5}$ Since reaching a peak in the late $1980 \mathrm{~s}$, the number of incidents has been on the decline. This finding contrasts with the general notion that terrorism has become an everincreasing threat. The number of people killed in terrorist incidents also varies considerably, from 34 in 1968 to 3,250 in 2001. No clear trend is visible and the series is greatly influenced

\footnotetext{
${ }^{5}$ It is, however, important to keep in mind that international terrorist acts are only a small fraction of all terrorist attacks taking place. In the years 1998 to 2002, the number of recorded domestic terrorist incidents was around 11 times higher than the number of international terrorist incidents; the respective number for fatalities is around 4 times higher (see the RAND-MIPT Terrorism Databases; www.mipt.org).
} 
by spectacular events, such as the simultaneous bombing of the American embassies in Kenya and Tanzania in 1998 and the attacks of September 11, 2001. As these series exhibit, the level of international terrorist acts is on the decline, while the number of fatalities has not been reduced as much. This implies that terrorism has become increasingly lethal - a common observation made by scholars studying terrorism. According to Enders and Sandler (2002), an incident in recent years is about 17 percentage points more likely to result in casualties than in the 1970s. This increase in lethality has been attributed to the increasing proportion of fundamentalist terrorist groups seeking mass casualties of innocent people to make their cause more widely known. In contrast, the leftist-based terrorists and nationalist terrorists want to instigate a revolution and aim at winning the hearts of the people. They therefore avoid killing or maiming innocent people not directly connected with the existing political and economic regime.

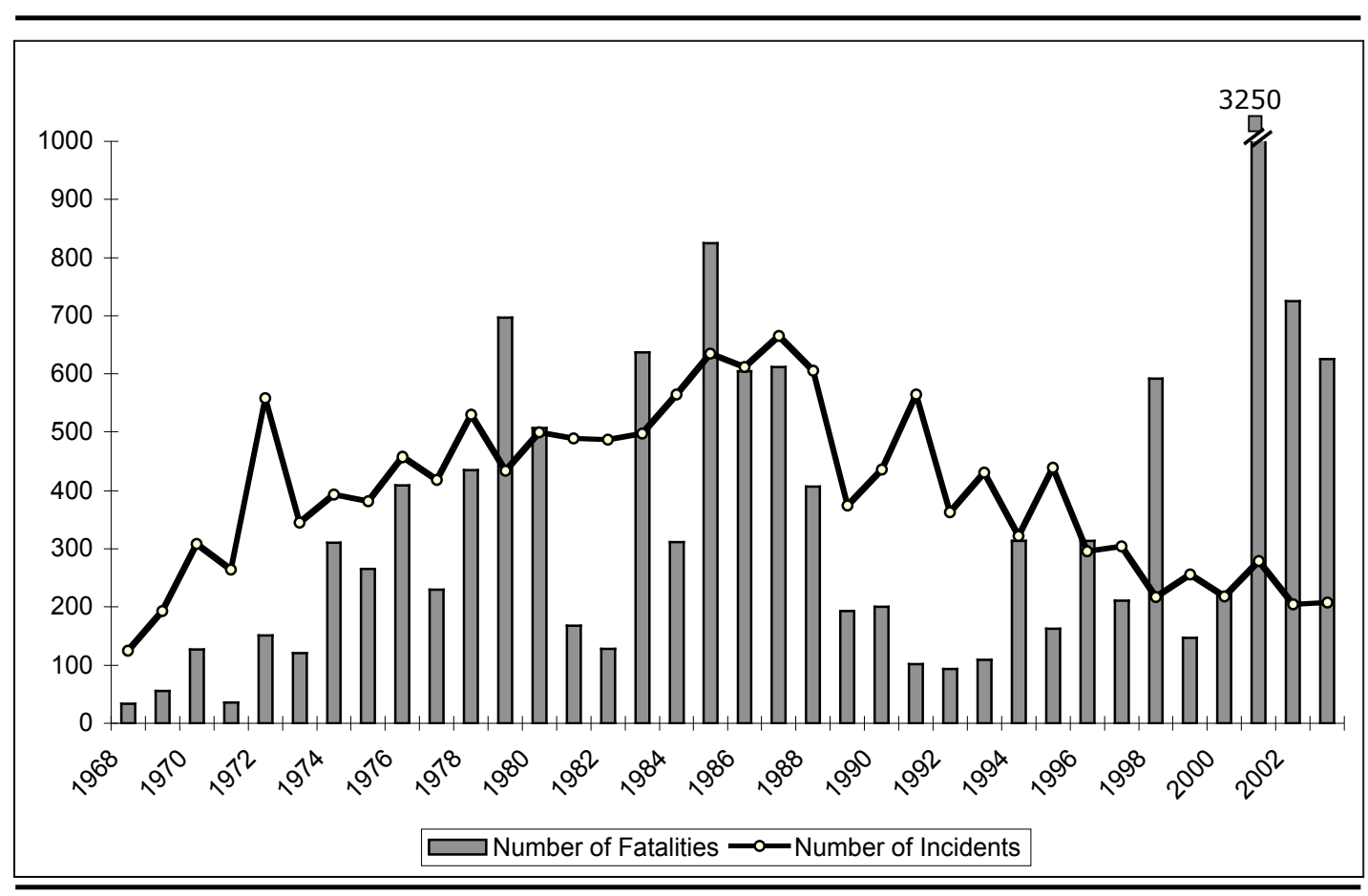

Source: US Department of State (various years) and Sandler and Enders (2004).

Figure 1. International terrorism, 1968-2003, number of incidents and number of fatalities

Further, using spectral analysis on a quarterly index of various terrorist activities (ITERATE, International Terrorism: Attributes of Terrorist Events; see Mickolus 1982 and Mickolus et al. 1989; 1993), a number of cycles have been identified (Enders and Sandler, 2002). Logistically complicated incidents, such as large-scale suicide car bombings, the hijacking of 
planes and assassinations have longer cycles than less sophisticated events. Terrorist activity developing in cycles, rather than as a continuous movement in one direction, has been attributed to various causes: demonstration and imitation effects act as propagators; economies of scale in planning terrorist incidents lower the cost for a restricted period of time; after a terrorist act there is a public outcry, inducing the authorities to take drastic measures which, again for a restricted period of time, reduce international terrorist activity. This "attack-counterattack cycle" results in fluctuations.

\section{Terrorism's impact on various aspects of the economy}

Over the last few years, scholars have analyzed the effects terrorist acts have on various aspects of the economy. In the following, the results for tourism, foreign direct investment, savings and consumption, investment, stock markets, foreign trade, the urban economy (including the costs of the attacks of September 11,2002), and overall economic development are surveyed.

1. Tourism. Tourists have become a frequent target of terrorist activities in recent years, ${ }^{6}$ generating huge resonance in the media. Examples are the Luxor massacre in 1997, in which members of an Egyptian Islamic group shot dead 58 foreign tourists visiting the temple of Queen Hatshepsut in the Valley of the Queens, and the bombing of a disco in Bali in 2002, costing the lives of almost 200 tourists. There is a simple rationale for these attacks. Individuals planning their holidays are less likely to choose a destination with a higher threat of terrorist attacks. Host countries providing tourism services, which can be easily substituted, are, therefore, negatively affected by terrorist attacks to a substantial extent. The expected reactions from consumers make the bombing, shooting and kidnapping of tourists attractive strategies for terrorists who want to inflict economic damage, when pursuing their political goals. There is a fast growing literature evaluating the effects of terrorism on tourism, focusing on the number of tourists and lost revenues in the industry. Special attention is given to substitution issues and the temporal structure of the effects.

In an early, influential paper, Enders and Sandler (1991) study the relationship between international terrorism and tourism in Spain. They use monthly data on terrorist incidents and combine it with the number of foreign visitors in Spain between 1970 and 1988, applying VAR methodology. It is estimated that a typical terrorist act in Spain scares away over

\footnotetext{
${ }^{6}$ It is argued that tighter security measures for military and government facilities made tourists relatively more attractive for terrorist attacks (see e.g. Im, Cauley and Sandler, 1987).
} 
140,000 tourists, when all the monthly impacts are combined. In 1988, 5.392 million foreigners visited Spain and 18 international terrorist incidents took place. Hence without these incidents, 1.5 times as many tourists would have visited Spain in 1988.

Careful econometric analyses reveal similar repercussions from terrorism on other tourist destinations. In a time-series analysis based on quarterly terrorism data and the ARIMA technique, Enders, Sandler and Parise (1992) quantify the present value of loss in tourism revenues for a sample of European countries. According to their calculations, Austria, Italy and Greece lost $\$ 4.538$ billion, $\$ 1.159$ billion and $\$ 0.77$ billion respectively between 1974 and 1988 (in 1988 terms, using a real interest rate of 5\%). For comparative purposes, total revenues in these countries in 1988 amounted to $\$ 11.149$ billion, $\$ 19.311$ billion and $\$ 3.29$ billion respectively. For the same period, continental Europe as a whole lost $\$ 16.145$ billion due to terrorism (total tourist revenues in 1988 were $\$ 74.401$ billion). Fleischer and Buccola (2002) estimate a supply and demand model of the Israeli hotel industry to assess the impact of terrorism. Foreign demand and equilibrium prices are allowed to be influenced by a monthly index, capturing the severity of the terrorist campaign in Israel. The annual revenue shortfalls between 1992 and 1998 in the market with foreign visitors sum up to approximately $\$ 50$ million (1998 present value discounted at $5 \%$ ) or $1.27 \%$ of total revenues in this period. Though these revenue losses are relatively modest, they increase with a deterioration of the situation. In 1996, a year of Middle East unrest, the revenue shortfall amounted to $2.55 \%$. Further, it is claimed that, due to inelastic local demand, hotels could not easily compensate these losses by cutting prices.

Two recent studies look at the effect of an intensification of extraordinary terrorist events on US tourist receipts and US airline demand. Sloboda (2003) uses ARMAX methodology to analyze annual time series of the number of terror attacks on US interests and US tourism receipts for the period 1988 to 2001, and estimates the effect of the Gulf War in 1991 and the accompanying increase in anti-American attacks on tourism revenues. In 1991, the number of incidents on US interests roughly doubled; this shock had a temporary negative impact on the tourism industry, which lasted until 2000. Aggregating the annual impacts of this initial shock (i.e. the impact of the increase in terrorism in later years is not included), total losses in revenue are approximately $\$ 57$ billion (1996 present value discounted at 5\%). Ito and Lee (2005) assess the impact of the September 11 attacks and the imposition of stringent new security requirements on domestic airline demand in the USA. The authors estimate a reduced form model of demand for air services with monthly time-series data since 1986 and model 
the post-September 11 period as an attenuating shock process that has both a transitory and an ongoing component. After controlling for cyclical, seasonal and other unique events impacting the industry, the initial demand shock is estimated to be more than $30 \%$ measured in revenue passenger miles (RPMs), and 7.3\% measured in yields. The decline in yield is smaller because a large number of airline tickets are purchased well in advance. In addition to the transitory shock, there is an ongoing downward shift in the demand of $7.4 \%$ measured in RPMs and of $10 \%$ measured in yields. The decline in demand is especially pronounced in the short-haul market, where more substitution possibilities are available. On the basis of a counterfactual demand prediction the authors conclude that the terror attacks and security measures account for roughly $94 \%$ of the decline in RPMs from the historical peak.

Estimated impacts of terrorism on tourism vary considerably, because the structure of the tourism industry and terror campaigns differ, not only across countries, but also over time. This hampers comparisons between studies. Instead, it emphasizes the importance of differentiating between different types of attacks, e.g. the location of an attack (i.e. whether it takes place in an urban or a rural area) and the number of casualties (see e.g. Drakos and Kutan, 2003).

Some scholars argue that terrorism could also be a reaction to irresponsible tourism development (e.g. Aziz, 1995, p. 93, for Egypt). In the aforementioned study for Spain by Enders and Sandler (1991), the argument is empirically assessed. It is found that causality is unidirectional, i.e. terrorism affects the inflow of tourists, but not the reverse.

The figures presented so far measure how the tourism industry in a particular country (or region) is affected by terrorist attacks taking place in that country (or region). However, two interdependencies between different countries' tourism industries and their terrorist campaigns are possible. On the one hand, the deterrent effect of terrorism on tourists in a particular country may benefit the tourism industries in alternative destinations. On the other hand, tourists may fear that terrorism could spill over into countries previously not involved and, therefore, abstain from visiting neighbouring countries. Though the substitution effect and the contagion effect (or negative externality) are countervailing, they can be simultaneously present. The regional interdependencies are explicitly modeled in the analysis of Drakos and Kutan (2003). Using monthly data for the period 1991 to 2000 and employing the SURE method, they investigate the effect of terrorism in Greece, Israel and Turkey on each other's market share, with Italy serving as a control country, representing the rest of the Mediterranean region. Their findings indicate that there are significant substitution effects. 
But there is also empirical evidence for the contagion effect: only around $11 \%$ of aggregate loss in market shares is directed toward other destinations within the group of countries under consideration, whereas around $89 \%$ flows out of the region. Enders, Sandler and Parise (1992) study the effects of terrorism for a series of European countries. They estimate the aggregate losses in revenue for Austria, Greece and Italy to amount to \$ 4.467 billion. Although they find no significant effect of terrorism in other continental European countries on the tourism revenues, the loss of tourism revenues due to terrorism for continental Europe as a whole is estimated to be $\$ 16.145$ billion. Therefore, continental Europe as a whole is much more negatively affected by terrorism than the sum of the country-by-country effects would imply. This result is again evidence for a contagion effect or negative externalities. The contagion and substitution effects have been empirically established for the tourism industry. However, these interdependencies are likely to be of general importance.

A note of caution is in order with regard to the temporal patterns of the impact of terrorism on tourism. ${ }^{7}$ The temporal pattern depends on the type of attacks in a particular country, and the market structure as well as the type of time-series used by researchers. Time-series on the number of actual visits are likely to respond more quickly to a terrorist incident than timeseries on tourism revenues, due to long-term contracts between tourist destinations and tour operators. Nevertheless, surprisingly different time spans are estimated until tourism begins to respond to a terrorist incident after it has elapsed. While Enders and Sandler (1991) and Fleischer and Buccola (2002) find relatively immediate effects of terrorism on tourism, i.e. after two to three months, for Spain and Israel respectively, Enders, Sandler and Parise (1992) find tourism to be unaffected by a terrorist incident until a full 18 to 21 months afterwards in the case of continental Europe and Austria respectively.

To summarize, terrorism systematically influences tourists' choice of destination and can, therefore, substantially negatively affect a host country. Moreover, the effect is long-lasting and has an impact on the demand for tourism in neighbouring countries. It remains an open question whether tourists' reactions to the threat of terrorism are rational. According to a RAND survey conducted in 1989, a third of those Americans interviewed said they would refuse the opportunity to travel abroad because of the risk of terrorism (Downes-Le Guin and Hoffman, 1993). It is hard to think of similar precautionary measures against life-threatening eventualities taking place with the same likelihood. More generally, Viscusi and Zeckhauser

\footnotetext{
${ }^{7}$ This is particularly important as, in studies based on time-series methods, the monthly or quarterly impacts are aggregated to assess the total impact of a terrorist incident. Hence, the plausibility of the temporal pattern needs careful attention.
} 
(2003) find that people are subject to a propensity to predict worst-case scenarios in assessing terrorism risks and are prone to anomalies known from other risk perception contexts. Similarly, Sunstein (2003) shows that individuals focus on the badness of the outcome rather than on the probability that it will occur. The "probability neglect" results in fear that greatly exceeds discounted harm.

2. Foreign direct investment (FDI). Terrorism affects the allocation decision of firms investing money in real foreign assets. Terrorists can quite easily attack and damage foreign owned firms, seriously disrupting their activities. As the foreigners have a large choice of countries to invest in, even quite mild terrorist activities tend to considerably reduce the inflow of capital to a terror-stricken country (see Abadie and Gardeazabal, 2005, for a formal exposition of this argument).

This has been well documented in the case of Spain and Greece, again using VAR methodology and quarterly terrorism data (Enders and Sandler, 1996). ${ }^{8}$ In Spain, terrorism is estimated to have reduced annual FDI inflow by $13.5 \%$ on average for the period 1975-1991. This translates into a decline in real FDI of almost 500 million dollars. In a similar period of time (1976-1991), Greece was plagued by two major terrorist organizations, the 17 November and the Revolutionary Popular Struggle. Both are extreme left-wing movements. The reduction of FDI was estimated to be, on average, $11.9 \%$ annually. This translates into a loss amounting to almost 400 million dollars. These results are corroborated by Abadie and Gardeazabal (2005) in a cross-section analysis for a sample of 110 countries. Using a measure of terrorism risk constructed by an international risk agency, they find a large negative effect on countries' net stock of FDI that is statistically significant and robust to various specifications. A one standard deviation change in terrorism risk, which is about an increase in terrorism risk from the level of Italy to the level of the US, induces a fall in the net position of about $5 \%$ of GDP. The inclusion of various political, economic, legal, tax, operational and security factors in the empirical framework suggests that terrorism, and more generally, security are among the most apparent and robust country-specific determinants of net FDI. As FDI is an important source of savings, a reduction in FDI negatively affects investment and economic growth. Moreover, the transfer of technological know-how into the country is reduced, again putting a damper on growth. Thus, the economic costs are substantial.

\footnotetext{
${ }^{8}$ For three larger European nations, namely France, West Germany and Italy, Enders and Sandler (1996) find no impact of terrorism on FDI.
} 
3. Savings and consumption. Apart from foreign direct investment, the investment rate is mainly constrained by the domestic savings rate. Consumption and, hence, savings rates may be affected by terrorist activity in different ways. On the one hand, political violence might increase perceived risks associated with savings, either because legal claims on assets are compromised or because individuals are prevented from spending the money their savings have earned. On the other hand, terrorism may induce individuals to place their money in safe havens rather than buy, for example, durable consumer goods. The two effects point in opposite directions; how consumption is affected by terrorism is, therefore, ultimately an empirical question. However, the empirical evidence is also ambiguous. Fielding (2003a) uses the variation in political tensions and violence in Israel over time to analyze the impact of political instability on Israeli aggregate consumption and thus on aggregate savings. He hypothesizes that the perceived insecurity depends mainly on the number of deaths in Israel proper and/or the number of deaths in the West Bank and Gaza areas, as well as the rate of growth of the Jewish settlements in the West Bank and Gaza areas. To investigate the impact of political instability on Israeli savings, Fielding (2003a) estimates a macro-econometric consumption function for Israel in the period 1989-1999 with quarterly data including the indicators of political instability mentioned. This permits the computation of how aggregate private sector consumption would change if there were to be a complete cessation of the conflict (measured by these indicators). If the number of fatalities in Israel proper decreased by its average level, consumption would fall by over $7 \%$. The respective number for a reduction of fatalities in the West Bank and Gaza areas is over 5\%. In contrast, the effect of freezing settlement construction would be negligibly small. Given Israel's poor savings performance, the effect would be huge. According to Fielding (2003a, p. 309), "the savings ratio in Israel would almost double as a result of a complete cessation of violence." Eckstein and Tsiddon (2004), in contrast, using VAR methodology estimates with quarterly data for the Israeli economy from 1950-2003, find a negative effect of terrorism on consumption. They expect that the continued terror (of a size similar to the number of deaths due to car accidents) will decrease annual consumption per capita by about $5 \%$ in 2004 . $^{9}$

4. Investment. The effect of terrorism on aggregate consumption and savings is important as it influences the investment level and, hence, economic growth. In addition, one can

\footnotetext{
${ }^{9}$ In an alternative approach, lower consumption growth and higher volatility in consumption due to terrorist attacks could be directly translated in a fraction of the level of initial consumption that households would be willing to give up in order to obtain a peaceful path. Hess (2003) provides an empirical application for a wide range of military conflicts.
} 
hypothesize that political violence not only affects the level of investments but also the composition of investments (Collier, 1999). Investments in non-traded capital goods, or nonresidential construction, are particularly risky in an environment of political instability. Such investments may, therefore, be reduced more than investments in machinery and equipment if political violence increases. Using a macro-econometric quarterly time-series model of investment in Israel for the period 1988-1998, conditioned on indicators of political instability, Fielding (2003b) investigates the impact of political instability on the level and composition of investments. To analyze the impact on the composition of investments, two investment equations, one for non-traded capital goods and one for machinery and equipment, are estimated. As an increase in investment in one category has a positive effect on investments in the other category, the dynamic effect between these two categories is important in calculating the total effect. The indicators of political instability are the number of Jews killed, the number of Palestinians killed and the rate of growth of the Jewish settlements in the West Bank and Gaza areas. Fielding (2003b) finds both the number of Israelis killed and the rate of growth of Jewish settlements to have a significantly negative impact on investment in non-residential construction. Manufacturing and equipment investment is significantly lowered by an increase in the total number of deaths and the rate of growth of settlements. ${ }^{10}$ Again, a "peace dividend", or the implicit increase in investment from a complete cessation of the conflict, can be estimated. Were the number of deaths to drop to zero, construction investment would be $27.9 \%$ higher and machinery and equipment investment would be $14.6 \%$ higher in the steady state. The different magnitude of these two effects confirms that investment composition is affected by political violence. In comparison to the impact of fatalities, the likely impact of a cessation of the expansion of settlements would again be small: the respective figures are $2.77 \%$ and $1.10 \%$. Overall, these effects are huge and would be even larger if second order effects were taken into consideration. For example, a stabilization of the political situation is likely to accelerate economic growth and, therefore, raise investment demand even further.

6. Stock markets. In the aftermath of spectacular attacks, the impact on financial markets is usually widely discussed in the media. Stock prices are a potentially informative measure of the economic damage of terrorism. Stock prices reflect expected future gains of a company, as well as the likelihood that these expected gains materialize. Terrorist attacks influence

\footnotetext{
${ }^{10}$ Why the different investment decisions are influenced by different fatality series remains a puzzle (Fielding, 2003b, p. 175).
} 
both: (i) Expected profits are lower if security measures increase the costs of production and doing business, and if consumers' fear reduces demand, like in the airline industry. (ii) The risk premium is higher when terrorism leads to increased uncertainty about a firm's prospects on the market. ${ }^{11}$ Empirically, the difficulty is in disentangling investors' decentralized evaluation of a firm's costs from terrorism, as reflected in the stock price, from a host of other factors. When looking for a contra factual market capitalization, one has, for example, to take into consideration that stock prices already reflect expected terrorist attacks before any event actually occurs. Previous research, therefore, has concentrated on single unexpected events or intensifications of terrorist activities.

An event which has been carefully analyzed is the cease-fire the Basque ETA declared between 1998 and 1999 (Abadie and Gardeazabal, 2003). This can be taken to be a natural experiment to estimate the cost of the terrorist conflict in terms of its effect on the stock value of a sample of Basque and non-Basque firms. If the terrorist conflict was perceived to have a negative effect on the Basque economy, stocks of firms with a significant part of their business activity in the Basque country should exhibit a positive relative performance when the truce began, and a negative relative performance when the truce ended. Basque stocks did indeed outperform non-Basque stocks as the truce became credible. The compounded abnormal returns for the 22 trading sessions of the good news period were $10.14 \%$ for the Basque portfolio relative to the non-Basque portfolio. At the end of the cease-fire, Basque stocks showed a negative performance relative to non-Basque stocks (with a relative loss over 66 trading sessions of $11.21 \%$ ).

In a broad event study for 14 terrorist/military attacks, returns on the US capital market are analyzed (Chen and Siems, 2004). Empirically, deviations of the Dow Jones Industrial stock index returns from past average returns (30 to 11 trading days before the event) are studied for different time frames. Military attacks in the past, like the invasion of France (May 12, 1940), or the one in North Korea (June 25, 1950), led to substantial negative cumulative abnormal returns when measured over 11 trading days. In contrast, there are no abnormal returns even on the actual day of the event of terrorist bombing attacks on Pan Am (December 21, 1988), the World Trade Center (February 26, 1993), Oklahoma City (April 19,

\footnotetext{
${ }^{11}$ The effect of terrorism on the systematic risk (beta) is studied for the events of September 11. In a sample of US firms from various sectors, models with time-varying betas find very heterogeneous effects of the event (Choudhry, 2005). For the airline industry around the world, however, there is a clear structural break. Conditional systematic risk, on average, doubled following September 11, 2001, whereby US airlines were most affected (Drakos, 2004).
} 
1995) or the US Embassy in Kenya (August 7, 1998). The single recent terrorist event, that even after six trading days showed statistically significantly negative cumulative abnormal returns, was September 11, 2001.

It is, however, difficult to relate the size and duration of abnormal returns to fundamental economic costs. Stock market fluctuations are likely to be larger than the underlying changes in fundamental values, because investors also buy and sell based on expectations about others' behaviour (Shiller, 2003). This may explain why, after months of experience with the Israeli Palestinian conflict, the stock market in Israel still reacts with a similar magnitude to suicide bombings (Eldor and Melnick, 2004), although one might think that underlying fundamental expectations do not systematically change with each new incident. Overall, the Israeli Palestinian conflict reduced the stock market capitalization substantially. Whilst up until the intensification of the conflict on September 27, 2000, S\&P 500 and the Israeli stock market developed in a very similar way, after this date the latter's performance dropped considerably. Compared to a simulation without terrorism, the index was $30 \%$ lower in June 30, 2003 (Eldor and Melnick, 2004).

Some multiplier of terrorist attacks on firm values lies in the capital market itself. As far as events affect the technological functioning of capital markets, for example, by interrupted interbank payments, liquidity shortages can lead to reduced system stability, even with the danger of consumer panic. Recent experience with the mature US banking system, however, shows that an adequate provision of liquidity by the central bank can prevent such potential damage. After September 11, 2001, the Federal Reserve at one point injected more than $\$ 100$ billion in additional liquidity (Lacker, 2004).

7. Foreign trade. Terrorist activities can affect foreign trade in several ways. First, the costs of doing business are raised by a general increase in insecurity as a result of terrorism. Second, augmented security measures in response to a terrorist campaign increase transaction costs. Third, there is the risk of a direct destruction of traded goods. The repeated attacks on oil pipelines in Iraq after the fall of Saddam Hussein, which temporarily paralyzed oil exports, are a recent example of the latter risk. Another example is the attack launched on the French supertanker "Limburg" off Yemen's coast in October 2002. In many countries one of the largest export industries is the tourism industry. As already discussed, this industry is directly affected by terrorism. 
Nitsch and Schumacher (2004) use an extended gravity model, containing the conventional determinants and, in addition, the annual number of international terrorist attacks in a country to assess the impact of terrorism on trade between more than 200 countries for the period 1968 to 1979 . According to their results, countries targeted by terrorism trade significantly less with each other than countries not affected by terrorism. Moreover, the effect is economically large: a doubling of the number of terrorist incidents reduces the bilateral trade flows by $4 \%$.

8. Urban economy. Terrorism may influence the relative advantage of living in a city compared to living in the countryside, and may thus affect urbanization: cities can exploit the positive economies of scale of defending their population. At the same time, the high population density makes cities an attractive target for terrorists. Finally, violence and terrorism raise transport costs. Transport costs can be substituted by closer physical vicinity. The last two influences are most relevant for modern terrorism, but they point in opposite directions. An analysis of the population development in London, Jerusalem and Tel Aviv indicates that terrorism has had little if any impact. Despite the relative safety of Tel Aviv, its population growth over the past 50 years actually lags behind that of Jerusalem (Glaeser and Shapiro, 2002). Similarly, cross-country evidence suggests that the overall impact of terrorism on urbanization is likely to be small. Glaeser and Shapiro (2002) regress a dummy variable that indicates whether a country experienced terrorism in the period 1968 to 1977 and, alternatively, the $\log$ number of terrorist incidents in this period on the extent of urbanization in 1978 and the number of skyscrapers built. While there is a positive relationship between terrorism and the extent of urbanization, Glaeser and Shapiro (2002) assert that "this link is small, statistically weak, and causally dubious" (p. 223). No evidence is found for an effect of terrorism on the number of tall buildings built in a country. ${ }^{12}$

Various studies have estimated the economic effects of the terrorist attacks on September 11, 2001. The direct costs consist of the destruction of infrastructure and human capital. The collapse of the twin towers destroyed 13 million square feet of real estate, and $30 \%$ of superior office space in downtown New York. But this accounts for only $4 \%$ of the total office space situated in Manhattan. One estimate of the real and human capital costs ranges from 25 to 60 billion dollars (Becker and Murphy, 2001). Another study estimates the human capital loss to be 40 billion dollars, and the property loss to be between 10 and 13 billion

\footnotetext{
${ }^{12}$ Other studies that discuss the impact of terrorism on urban development are Bram, Haughwout and Orr (2002), Harrigan and Martin (2002), Mills (2002) and Wildasin (2002).
} 
dollars (Navarro and Spencer, 2001). Yet another estimate of the total direct loss is 21.4 billion dollars (International Monetary Fund, 2001). Looking at the extent of destruction relative to the overall US productive capacity indicates that the damage was minor (Brauer, 2002). The estimates of between 10 and 60 billion dollars worth of damage resulting from the attacks of September 11, 2001 is relatively small compared to the American GNP of 10 trillion dollars.

However, the indirect costs may be substantial. They consist of the induced cost of doing business, for instance longer waitings at airports, higher friction and transactions costs in international trade, as well as the cost of the military and civilian resources used to fight terrorism. To achieve a significant reduction in the probability of falling prey to a terrorist attack is certainly expensive. The fraction of the economic potential that can be used for consumption today and in the future is significantly reduced. But it is impossible to attach any serious figure to these factors. This is particularly so if the effects outside the United States are also taken into account. Based on a computable general equilibrium model (Walkenhorst and Dihel, 2002), it has been estimated that the indirect cost of increased economic friction in international trade is larger for other regions of the world than for North America.

9. National income and growth. Estimating the overall effect of terrorism on the economy ${ }^{13}$ is faced with the problem of how the economy would have developed if there had been less terrorism, or no terrorism at all. To construct a counterfactual is not easy. An interesting attempt has been made for the Basque country, with a "synthetic" control region made up of other Spanish regions, but in many ways resembling the relevant economic characteristics of the Basque country before the onset of political terrorism by the ETA in the 1970s (Abadie and Gardeazabal, 2003). The subsequent economic development of this counterfactual synthetic region is compared to the actual experience of the Basque country. It is estimated that, after the outbreak of terrorism, the per capita GDP in the Basque country fell by about 10

\footnotetext{
${ }^{13}$ The effect of general political instability (or stable political institutions, alternatively) on the growth of national income has been analyzed using cross section data by Barro (1991), Alesina et al. (1996) and Acemoglu, Johnson and Robinson (2001) among others. The latter studies also address the problem of reverse causality: as argued by Olson (1982), political instability may not only be a cause but also an effect of economic fluctuations. The same might be true in the case of terrorism. A notable study analyzing the effect of income and education on terrorism is a paper by Krueger and Maleckova (2003). On the basis of a variety of evidence, such as the influence of living standards on the support for violent attacks by Palestinians on Israelis expressed in opinion polls and a comparison of the characteristics of the Hezbollah activists killed with those of the general Lebanese population, the authors conclude that terrorism is not a response to bad economic conditions: "[T]he evidence we have assembled does not indicate a connection between poverty and terrorism, and we are not aware of compelling evidence that points in the opposite direction" (Krueger and Maleckova, 2003, p. 121).
} 
percentage points relative to the control region. This gap tends to widen when terrorist activities are on the increase. If the terrorist activities by the ETA had a negative economic effect on other Spanish regions (included in the synthetic control), the GNP gap estimated for the Basque country is a lower bound. In contrast, if the terrorist activities diverted investment from the Basque country to other Spanish regions, the magnitude of the gap is artificially increased. However, the authors convincingly argue that the two biases are likely to be small.

An extensive VAR study of the macroeconomic effects of terrorism (Blomberg, Hess and Orphanides, 2004; see also Blomberg, Hess and Weerapana, 2004) uses a panel set with annual observations for 177 countries from 1968 to 2000. It controls for the interactions between terrorism and other forms of internal and external conflict and is therefore able to differentiate between similar types of political disruptions. On average, terrorism (captured by the ITERATE data) is found to depress economic growth in a marked, and statistically significant, way. However, this effect is considerably smaller and less persistent than that exerted by external wars and internal conflicts. Spending is diverted from investment to public expenditures. Interestingly enough, the negative association between terrorism and economic growth is small and statistically insignificant for advanced (OECD) economies, which are most affected by terrorism. The depressing effect of terrorism on economic growth appears to be most significant for developing countries. Overall, the relationship between terrorism and economic growth can mainly be attributed to country fixed effects.

Eckstein and Tsiddon (2004) focus on one dimension of terrorism, the insecurity which manifests in daily life. Increasing terror makes life less certain and shorter. ${ }^{14}$ Using a closedeconomy-infinite-horizon model, the government in charge of public security as a public good reduces the death toll by stepping up defence expenditures when terrorism increases. If it acts optimally, it does not fully offset the tide. A long-run equilibrium with an optimizing government is characterized by lower output, going with a higher intensity of terror. An econometric test for Israel, based on data from 1950 to 2003, indeed reveals an increase in the ratio of defence expenditures to GNP from $9 \%$ to $12 \%$ in the period of the Intifada (20002003:3) and a drastic reduction in output per capita. Over this period, output per capita declined annually by $3 \%$. If terrorism remains as high as it was in 2003, per capita GDP will be about $3.5 \%$ lower by $2004: 3$ than if terrorism stops.

\footnotetext{
${ }^{14}$ Other dimensions could be the effect of terror on the deterioration of health (thereby lowering productivity) and on human capital (Tsiddon, 1995).
} 
These effects of terrorist actions on the various sectors and the overall economy do not capture the total costs of terrorism. Non-market values are, by definition, excluded from these measures. The fear of individuals and the grief of the victims and the bereaved are disregarded. It follows that the damage perpetrated by terrorism may be considerably underestimated. If policy makers take the estimates discussed above seriously, they would allocate too little money to dealing with terrorism and rather use the funds and their energy for pursuing other goals. In the following section, therefore, methods are discussed for capturing total utility losses people suffer as a result of terrorist activities.

\section{Utility consequences of terrorism}

The disutility from the public bad, terrorism, like the benefits from public goods, is inherently difficult to measure. However, a wide variety of different approaches for the measurement of preferences has been developed (see, e.g., Freeman, 2003), in particular to value environmental quality and the cultural heritage. These approaches can potentially be applied to value the threat of terrorism as well. We briefly discuss existing techniques emphasizing possible advantages and likely drawbacks in the study of terrorism. The focus is on a new, and we think, promising approach: the life satisfaction approach.

\subsection{Traditional methods}

Two avenues have been pursued to infer and elicit individuals' preferences for public goods and externalities: stated preference methods on the one hand and revealed preference methods on the other hand. The most prominent exponent of the former is the contingent valuation method and of the latter the hedonic market approach.

1. Contingent valuation surveys enable researchers to assess the effect of a reduction of terrorism on utility, including non-use values. ${ }^{15}$ Terrorism is directly assessed, using survey questions on people's willingness to pay, for example, for a bisection of the number of terrorist incidents in a region. While this is an appealingly easy framework, there are a number of difficulties with this approach. The survey respondents find themselves in an unfamiliar situation and may be induced to give strategic responses. Important design issues to address these problems are the presentation of adequate information, a credible

\footnotetext{
${ }^{15}$ See Carson et al. (2003) for an elaborate and state-of-the-art contingent valuation study in the environmental realm. The credibility and validity of the results based on the contingent valuation method are the subject of a heated controversy in economic literature, as a symposium in the Journal of Economic Perspectives (Diamond and Hausman, 1994; Hanemann, 1994; Portney, 1994) demonstrates.
} 
(hypothetical) payment mechanism and the use of the incentive-compatible referendum format (Portney, 1994). In order to avoid symbolic valuation, a survey must also contain a detailed description of a hypothetical policy program, which the respondents believe to be capable of providing the public good in question, i.e. the reduction in terrorist incidents. In light of the failure of most traditional anti-terrorism policies, this is likely to be a difficult task.

A basic problem of applying contingent valuation to terrorism is that it is not obvious what preferences should enter. Two aspects are of particular importance. First, psychological anomalies play a major role. A vital aspect is that the disparity between gains and losses matters. It is therefore important whether one asks what people would be prepared to pay in order to reduce terrorism, or what they would be prepared to accept in order to tolerate some degree of terrorism. Second, terrorism is an international phenomenon and terrorists often have no difficulty in moving from one country to another. For this reason, the anti-terrorism policies of a particular country produce international or even global externalities. An antiterrorism policy that successfully prevents terrorists from attacking a particular country increases the probability of attacks in other countries (Lee, 1988; Sandler and Lapan, 1988). On the other hand, anti-terrorism policies, based on positive incentives (Frey and Luechinger, 2003; 2004), entail positive externalities for other countries. The dimension of the relevant population, whose values for security from a specific terrorist campaign should be sought, is a question of values. Another problem with a contingent valuation survey is that individuals evaluate specific objects or specific victims quite differently from a non-specified, or statistical, victim (Schelling, 1968; Small and Loewenstein, 2003). People are prepared to spend much less on efforts to save as yet unidentified lives than identified lives from terrorist attacks

Contingent valuation surveys may nevertheless provide valuable insights into the utility losses imposed by terrorism. So far there is only one survey study that examines the trade-off between money and terrorism risk (Viscusi and Zeckhauser, 2003). The main research interest of this study, however, is whether the answers reflect a rational response to terrorism risks. The subjects were asked what increase in the price of a plane ticket they would be willing to pay if the risk of a terrorist attack on an airplane were to be reduced (a) by $50 \%$, (b) to one in a million per flight, (c) to one in 10 million per flight or finally (d) to zero. The average increase in price subjects are willing to pay for a plane ticket is (a) ca. $25 \%$, (b) ca. $38 \%$, (c) 
ca. $53 \%$ and (d) ca. $70 \%$ respectively. These estimates reflect a well-known premium for reaching a zero risk level (see Kahneman and Tversky, 1979 for the "certainty effect").

2. The hedonic market approach is based on the idea that markets, primarily the housing and the labour markets, reflect the utility losses imposed on individuals by terrorist activity. ${ }^{16}$ Higher wages must be paid to compensate employees for the disamenities incurred by working in a region ridden with terrorism. Similarly, the rent for housing and land to be paid is negatively affected by terrorism. In equilibrium, the marginal implicit compensations associated with working or living in a region plagued by terrorism equals the corresponding marginal willingness to accept. To our knowledge, no study employs the hedonic market approach in particular, or revealed preference methods in general, to evaluate the consequences of terrorism.

A major drawback of the hedonic market approach is that it is based on the assumption that the market is perfect and in equilibrium, and fully reflects changes in the amount and intensity of terrorism. The adjustment that people are likely to make in response to changes in the intensity of a terrorist campaign, as well as changes in the supply side of the hedonic property market, needs to be accounted for (Freeman, 2003, pp. 373 and 381). Similarly, it might be difficult to isolate the effects of terrorism from those caused by government reactions. Indirect estimations of utility losses can only be applied if the individuals are aware of changes in the terrorism risk over time and/or differences across regions. Individuals' difficulties in assessing terrorism risk may, therefore, hamper the application of revealed preference methods (see e.g. Downes-Le Guin and Hoffman, 1993; Sunstein, 2003; Viscusi and Zeckhauser, 2003). This also implies that unanticipated and cataclysmic terrorist acts cannot be evaluated. Further, revealed preferences may reflect anticipated future risk rather than current risk. Finally, revealed preference methods cannot capture non-use values.

\subsection{Effects on life satisfaction}

People's assessment of their overall well-being can be directly captured by measures of reported subjective well-being. In large representative questionnaire studies, individuals are asked about their level of life satisfaction or happiness. This opens new possibilities for

\footnotetext{
${ }^{16}$ Exemplary contributions are Blomquist; Berger and Hoehn (1988) and Chay and Greenstone (2004). Another revealed preference method that potentially allows for the assessment of utility losses due to terrorism is the defense expenditure approach or averting behavior method. The basic idea of this method is that individuals' evaluation for a change in the provision of a public good is reflected in accompanying changes in expenditures for substitutive private goods (see e.g. Zeckhauser and Fisher, 1976).
} 
studying important economic questions (see Frey and Stutzer, 2002a,b, for surveys). For example, with reported subjective well-being as a proxy measure for utility, it is now a straightforward strategy to directly evaluate public goods, or a public bad like terrorism, in utility terms. By measuring the marginal utility of a public good or the marginal disutility of a public bad, as well as the marginal utility of income, the marginal rate of substitution between income and the public good can be calculated. This allows for the computation of relevant welfare measures for marginal and infra-marginal changes in the public good provision. We call this the life satisfaction approach. ${ }^{17}$

It stands to reason that people living in a country rife with terrorism are less happy than those living under more orderly political conditions. An example is the Dominican Republic in 1962 where, after president Trujillo's murder, the political situation was very unsettled and political chaos was a real threat. The level of life satisfaction recorded in that country was the lowest ever recorded, namely 1.6 on a 0 to 10 scale. In contrast, in politically stable democracies, such as Switzerland, Norway or Denmark, the population expresses high levels of life satisfaction. The corresponding values were, for example, in the 1990s 8.16 for Denmark, 8.02 for Switzerland and 7.66 for Norway. Thus, happiness and political stability seem to be closely related.

The life satisfaction approach has several important advantages over the approaches discussed so far in measuring people's utility losses due to terrorist activity. Contrary to contingent valuation surveys, this approach does not rely on asking people how they value a public good or an anti-terrorism policy. The hypothetical nature of these questions and the unfamiliar situation for the respondents are the principal reasons for most of the scepticism about, and problems concerning, the contingent valuation method. It is a demanding cognitive task, and superficial or socially desirable responses, without adequate consideration of the budget constraint or substitutes, can result. To correctly state one's own current level of life satisfaction, in contrast, is much less demanding and strategic responses are unlikely. Similarly, the stringent conditions of the approaches based on revealed preferences, like housing or labour market equilibrium in the case of the hedonic market approach, do not have to be met in order to evaluate welfare effects through the use of life satisfaction data. ${ }^{18}$

\footnotetext{
${ }^{17}$ See Welsch (2002) and van Praag and Baarsma (2005) for the evaluation of externalities in the environmental realm with reported subjective well-being data.

${ }^{18}$ However, there are the conditions of cardinality and interpersonal comparability of the individual statements of well-being. Although economists are likely to be skeptical about both claims, there is a lot of evidence that both of them may be less of a problem on a practical level than on a theoretical
} 
Frey, Luechinger and Stutzer (2004) use the life satisfaction approach to assess the costs of terrorism in France, the United Kingdom and the Republic of Ireland. By way of illustration, an analysis of the Northern Ireland conflict is presented here.

Life satisfaction data are taken from the Euro-Barometer Survey Series (1970-1999); the variable is the categorical response to the following question: "On the whole, are you very satisfied [4], fairly satisfied [3], not very satisfied [2], or not at all satisfied [1] with the life you lead?" As an indicator for the salience and intensity of terrorist activity, the number of deaths resulting from the conflict in Northern Ireland is taken, as compiled by Sutton (1994; an updated index is provided by the Conflict Archive on the Internet (www.cain.ulst.ac.uk)). This indicator is not restricted to terrorism in particular, but includes political violence in general. In order to identify the effect of terrorism on individuals' life satisfaction, the authors use a combined time-series (for the period 1975 to 1998) and cross-section analysis (with Northern Ireland, the rest of the United Kingdom and the Republic of Ireland). Specifically, a micro-econometric happiness function is specified, whereby the life satisfaction of an individual living in a particular region at a particular time is explained by differences in the level of terrorism across the three regions and over time, the individual's household income, other personal and socio-demographic characteristics, as well as region and time fixed effects.

The estimation results suggest that the number of terrorist fatalities has a statistically significant negative effect on reported life satisfaction. For an increase of one standard deviation in the number of recorded fatalities, i.e. an increase of 53.7 fatalities, life satisfaction is lowered by 0.041 on the four-point scale. This effect is about a tenth of the effect of being unemployed rather than employed. Thus, the indicator for terrorism is correlated with people's subjective well-being in a sizeable way.

The estimated coefficients for terrorism and individual income can be used to calculate the hypothetical willingness-to-pay for a discrete change in the level of terrorism. Frey, Luechinger and Stutzer (2004) calculate a hypothetical willingness-to-pay of a resident of Northern Ireland for a reduction in the number of fatalities to the average level of Great Britain and the Republic of Ireland. Accordingly, a resident of Northern Ireland (with average household income) would be willing to pay around $41 \%$ of his income for a reduction in

level (see e.g. Kahneman, 1999; Ferrer-i-Carbonell and Frijters, 2004). Furthermore, the life satisfaction approach has several problems in common with the revealed preference methods: (i) It is not immune to spurious correlations that are the result of omitted variables, (ii) perceived risks must be correlated with objective risk measures and (iii) pure public goods and, therefore, the existence value cannot be captured. 
terrorist activity to the level that prevails in the more peaceful parts of the country or the sister republic. This estimate is surprisingly high. However, it might to some extent reflect the ferocity of the conflict. After all, Northern Ireland was on the brink of all-out civil war; Fay, Morrissey and Smyth (1999, p. 204), for example, estimate that around two thirds of the Northern Irish population live in households where someone has been injured in a conflict related incident.

This result indicates that utility losses may far exceed the economic consequences discussed in section 3 .

\section{Concluding remarks}

A lot of the research on terrorism, even by economists, is based on the number of terrorist incidents and casualties. As our survey shows, it is possible to go much further. A sizeable literature already exists on the economic consequences of terrorism, such as on tourism, foreign direct investment, savings and consumption, investment, stock prices, foreign trade and the urban economy as well as national income and growth. But studies so far have neglected to analyze the utility losses induced by terrorism, which we suggest are considerably larger than the purely economic losses. The standard method of measuring the benefits (or costs) of public goods (or bads) is to employ stated preference methods (in particular, contingent valuation surveys) and revealed preference methods (for example, by looking at hedonic markets). However, these approaches face considerable problems, especially when an attempt is made to estimate the utility losses resulting from terrorism, and so have not yet been used for that purpose.

We propose a new approach based on life satisfaction or subjective well-being data, which are collected independently of the data on terrorist activities, and are therefore not biased by any immediate priming effects. The estimates presented reveal that terrorism leads a considerable reduction in life satisfaction, suggesting that individuals incur large utility losses. Individuals would need to receive substantial increases in income in order to compensate for the harm inflicted by terrorism. The results reported here refer only to the Northern Ireland conflict. It would certainly be necessary to apply this approach to different countries, different periods of history and different types of terrorism. Future research needs to undertake systematic comparisons between the standard methods of measuring the benefits of public goods and the life satisfaction approach. It should be taken into account that the measures of life satisfaction applied here could be improved upon. The life satisfaction approach should therefore not be 
criticized solely on the basis of the existing quality of subjective well-being measures. Rather, scholars need to evaluate the extent to which a meaningful relationship can be established, and econometrically estimated, between life satisfaction data and terrorist acts.

Future research should also endeavour to distinguish between the direct and indirect consequences of a terrorist incident. The indirect consequences include the costs imposed on the population of the targeted country by the political reactions. As discussed above, numerous reported estimates reflect the direct consequences of terrorism as well as the impact of the subsequent counter measures. In the case of foreign trade and the aviation industry, for example, enhanced security measures are likely to account to a considerable extent for the reduction in bilateral trade and the drop in demand. Political reactions may reflect voters' demands for increased security or politicians' strategic exploitation of the "rally round the flag" effect, and may range from increased expenditures for military and secret services to restrictions on human rights. More extensive studies would not only require data on the number and severity of terrorist attacks, but would also need to analyze the determinants of political actions imposing these indirect costs on the population.

\section{Acknowledgements}

The first part of the title is borrowed from a homonymous Economist-article (2004). We wish to thank a large number of scholars for comments on this paper. 


\section{References}

Abadie, Alberto and Gardeazabal, Javier (2003) The economic costs of conflict: A case study of the Basque Country. American Economic Review 93, 113-132

---- (2005) Terrorism and the world economy. Mimeo, Harvard University

Acemoglu, Daron, Johnson, Simon and Robinson, James A. (2001) The colonial origins of comparative development: An empirical investigation. American Economic Review 91, 1369-1401

Alesina, Alberto, Ozler, Sule, Roubini, Nouriel and Swagel, Phillip (1996) Political instability and economic growth. Journal of Economic Growth 1, 189-211

Aziz, Heba (1995) Understanding attacks on tourists in Egypt. Tourism Management 16, 91-95

Barro, Robert J. (1991) Economic growth in a cross section of countries. Quarterly Journal of Economics 106, 407-443

Becker, Gary S. and Murphy, Kevin (2001) Prosperity will rise out of the ashes. Wall Street Journal, October 29,2001

Berrebi, Claude and Klor, Esteban F. (2004) On terrorism and electoral outcomes: Theory and evidence from the Israeli-Palestinian conflict. Mimeo, Princeton University

Blomberg, S. Brock, Hess, Gregory D. and Orphanides, Athanasios (2004) The macroeconomic consequences of terrorism. Journal of Monetary Economics 51, 1007-1032

Blomberg, S. Brock, Hess, Gregory and Weerapana, Akila (2004) Economic conditions and terrorism. European Journal of Political Economy 20, 463-478

Blomquist, Glenn C., Berger, Mark C. and Hoehn, John P. (1988) New estimates of quality of life in urban areas. American Economic Review 78, 89-107

Bram, Jason, Haughwout, Andrew and Orr, James (2002) Has September 11 affected New York city's growth potential? Federal Reserve Bank of New York Economic Policy Review 8, 81-96

Brauer, Jurgen (2002) On the economics of terrorism. Phi Kappa Phi Forum 82

Brown, Jeffrey R. (2004) An empirical analysis of the economic impact of federal terrorism reinsurance. Journal of Monetary Economics 51, 861-898

Carson, Richard T., Mitchell, Robert C., Hanemann, W. Michael, Kopp, Raymond J., Presser, Stanley and Ruud, Paul A. (2003) Contingent valuation and lost passive use: Damages from the Exxon Valdez oil spill. Environmental and Resource Economics 25, 257-286

Chay, Kenneth Y. and Greenstone, Michael (2004) Does air quality matter? Evidence from the housing market. Journal of Political Economy 113, 376-424

Chen, Andrew H. and Siems, Thomas F. (2004) The effects of terrorism on global capital markets. European Journal of Political Economy 20, 349-366

Choudhry, Taufiq (2005) September 11 and time-varying beta of United States companies. Applied Financial Economics 15, 1227-1242

Collier, Paul (1999) On the economic consequences of civil war. Oxford Economic Papers 51, 168-183

Collier, Paul and Hoeffler, Anke (2004) Greed and grievance in civil war. Oxford Economic Papers 56, 563-596

Cummins, J. David and Lewis, Christopher M. (2003) Catastrophic events, parameter uncertainty and the breakdown of implicit long-term contracting: The case of terrorism insurance. Journal of Risk and Uncertainty 26, 153-178

Diamond, Peter A. and Hausman, Jerry A. (1994) Contingent valuation: Is some number better than no number? Journal of Economic Perspectives 8, 45-64

Downes-Le Guin, Theodore and Hoffman, Bruce (1993) The Impact of Terrorism on Public Opinion, 1988 to 1989. Santa Monica, CA: RAND Corporation

Drakos, Konstantinos (2004) Terrorism-induced structural shifts in financial risk: Airline stocks in the aftermath of the September 11th terror attacks. European Journal of Political Economy 20, 435-446

Drakos, Konstantinos and Kutan, Ali M. (2003) Regional effects of terrorism on tourism in three Mediterranean countries. Journal of Conflict Resolution 47, 621-641

Eckstein, Zvi and Tsiddon, Daniel (2004) Macroeconomic consequences of terror: Theory and the case of Israel. Journal of Monetary Economics 51, 971-1002

Economist (2004) Calculating tragedy: September 11th compensation. Economist, June 26, 2004: 84-85 
Eichenbaum, Martin and Fisher, Jonas D. M. (2005) Fiscal policy in the aftermath of 9/11. Journal of Money, Credit and Banking 37, 1-22

Eldor, Rafi and Melnick, Rafi (2004) Financial markets and terrorism. European Journal of Political Economy 20, 367-386

Enders, Walter and Sandler, Todd (1991) Causality between transnational terrorism and tourism: The case of Spain. Terrorism 14, 49-58

---- (1995) Terrorism: Theory and applications. In Keith Hartley and Todd Sandler (eds). Handbook of Defense Economics, vol. 1 (pp. 213-249). Amsterdam, New York and Oxford: Elsevier

---- (1996) Terrorism and foreign direct investment in Spain and Greece. Kyklos 49, 331-352

---- (2002) Patterns of transnational terrorism, 1970-1999: Alternative time-series estimates. International Studies Quarterly 46, 145-165

Enders, Walter, Sandler, Todd and Parise, Gerald F. (1992) An econometric analysis of the impact of terrorism on tourism. Kyklos 45, 531-554

Fay, Marie-Therese, Morrissey, Mike and Smyth, Marie (1999) Northern Ireland's Troubles: The Human Costs. London: Pluto Press

Ferrer-i-Carbonell, Ada and Frijters, Paul (2004) How important is methodology for the estimates of the determinants of happiness? Economic Journal 114, 641-659

Fielding, David (2003a) Counting the cost of the intifada: Consumption, saving and political instability in Israel. Public Choice 116, 297-312

---- (2003b) Modelling political instability and economic performance: Israeli investment during the intifada. Economica 70, 159-186

Financial Times (2004) After the Madrid bombings. Triumph of terrorism or victory for democracy? Spain's stunning election results asks tough question of Europe. Financial Times, March 16, 2004: 11

Fleischer, Aliza and Buccola, Steven (2002) War, terror, and the tourism market in Israel. Applied Economics 34, 1335-1343

Freeman, A. Myrick, III (2003) The Measurement of Environmental and Resource Values: Theory and Methods. Washington, D.C.: Resources for the Future

Frey, Bruno S. and Luechinger, Simon (2003) How to fight terrorism: Alternatives to deterrence. Defence and Peace Economics 14, 237-49

---- (2004) Decentralization as a disincentive for terror. European Journal of Political Economy 20, 509-515

Frey, Bruno S., Luechinger, Simon and Stutzer, Alois (2004) Valuing public goods: The life satisfaction approach. CESifo Working Paper No. 1158, Munich: CESifo

Frey, Bruno S. and Stutzer, Alois (2002a) Happiness and Economics: How the Economy and Institutions Affect Well-being. Princeton, NJ: Princeton University Press

---- (2002b) What can economists learn from happiness research? Journal of Economic Literature 40, 402-35

Garfinkel, Michelle R. (1990) Arming as a strategic investment in a cooperative equilibrium. American Economic Review 80, 50-68

---- (1994) Domestic politics and international conflict. American Economic Review 84, 1294-1309

Glaeser, Edward L. and Shapiro, Jesse M. (2002) Cities and warfare: The impact of terrorism on urban form. Journal of Urban Economics 51, 205-224

Grossman, Herschel I. (1991) A general equilibrium model of insurrections. American Economic Review 81, 912-21

Gupta, Sanjeev, Clements, Benedict, Bhattacharya, Rina and Chakravarti, Shamit (2004) Fiscal consequences of armed conflict and terrorism in low- and middle-income countries. European Journal of Political Economy 20, 403-421

Hanemann, W. Michael (1994) Valuing the environment through contingent valuation. Journal of Economic Perspectives 8, 19-43

Harrigan, James and Martin, Philippe (2002) Terrorism and the resilience of cities. Federal Reserve Bank of New York Economic Policy Review 8, 97-116

Hess, Gregory (2003) The economic welfare cost of conflict: An empirical assessment. CESifo Working Paper Series No. 852, Munich: CESifo

Hess, Gregory D. and Orphanides, Athanasios (1995) War politics: An economic, rational-voter framework. American Economic Review 85, 828-846 
---- (2001) Economic conditions, elections, and the magnitude of foreign conflicts. Journal of Public Economics $80,121-140$

Hoffman, Bruce (1998) Inside Terrorism. New York: Columbia University Press

Im, Eric Iksoon, Cauley, Jon and Sandler, Todd (1987) Cycles and substitutions in terrorist activities: A spectral approach. Kyklos 40, 238-255

International Monetary Fund (2001) How has September 11 influenced the global economy. World Economic Outlook 2001, Chapter 2

Ito, Harumi and Lee, Darin (2005) Assessing the impact of the September 11 terrorist attacks on U.S. airline demand. Journal of Economics and Business 57, 75-95

Kahneman, Daniel (1999) Objective happiness. In Daniel Kahneman, Ed Diener and Norbert Schwarz (eds). Well Being: The Foundations of Hedonic Psychology (pp. 3-25). New York, NY: Russell Sage Foundation

Kahneman, Daniel and Tversky, Amos (1979) Prospect theory: An analysis of decision under risk. Econometrica 47, 263-291

Keynes, John Maynard (1919) The Economic Consequences of Peace. London: Macmillan

Krueger, Alan B. and Maleckova, Jitka (2003) Education, poverty and terrorism: Is there a causal connection? Journal of Economic Perspectives 17, 119-144

Kunreuther, Howard, Michel-Kerjan, Erwann and Porter, Beverly (2003) Assessing, managing, and financing extreme events: Dealing with terrorism. NBER Working Paper No. w10179, Cambridge MA, National Bureau of Economic Research

Lacker, Jeffrey M. (2004) Payment system disruptions and the Federal Reserve following September 11, 2001. Journal of Monetary Economics 51, 935-965

Lee, Dwight R. (1988) Free riding and paid riding in the fight against terrorism. American Economic Review 78, 22-26

Mickolus, Edward F. (1982) International Terrorism: Attributes of Terrorist Events, 1968-1977 (Iterate 2). Dunn Loring, VA: Vinyard Software

Mickolus, Edward F., Sandler, Todd, Murdock, Jean M. and Fleming, Peter (1989) International Terrorism: Attributes of Terrorist Events, 1978-1987 (Iterate 3). Dunn Loring, VA: Vinyard Software

---- (1993) International Terrorism: Attributes of Terrorist Events, 1988-1991 (Iterate 4). Dunn Loring, VA: Vinyard Software

Miller, Abraham H. (1994) Comment on terrorism and democracy. Terrorism and Political Violence 6, 435-439

Mills, Edwin S. (2002) Terrorism and U.S. real estate. Journal of Urban Economics 51, 198-204

Navarro, Peter and Spencer, Aron (2001) September 2001: Assessing the cost of terrorism. Milken Institute Review 2, 16-31

Nitsch, Volker and Schumacher, Dieter (2004) Terrorism and international trade: An empirical investigation. European Journal of Political Economy 20, 423-433

Olson, Mancur Jr. (1982) The Rise and Decline of Nations: Economic Growth Stagflation and Social Rigidities. New Haven: Yale University Press

Pigou, Arthur Cecil (1916) The Economy and Finance of the War. Being a Discussion of the Real Costs of the War and the Way in Which They Should Be Met. London: J.M. Dent

---- (1921) The Political Economy of War. London: Macmillan

Portney, Paul R. (1994) The contingent valuation debate: Why economists should care. Journal of Economic Perspectives 8, 3-17

Robbins, Lionel C. (1940) The Economic Causes of War. London: Cape

Sandler, Todd and Enders, Walter (2004) An economic perspective on transnational terrorism. European Journal of Political Economy 20, 301-316

Sandler, Todd and Lapan, Harvey E. (1988) The calculus of dissent: An analysis of terrorists' choice of targets. Synthese 76, 245-261

Schelling, Thomas C. (1968) The life you save may be your own. In Samuel B. Chase (ed.). Problems in Public Expenditure Analysis (pp. 127-176). Washington D.C.: The Brookings Institution

Shiller, Robert J. (2003) From efficient markets theory to behavioral finance. Journal of Economic Perspectives 17, 83-104

Sloboda, Brian W. (2003) Assessing the effects of terrorism on tourism by use of time series methods. Tourism Economics 9, 179-190 
Small, Deborah A. and Loewenstein, George (2003) Helping a victim or helping the victim: Altruism and identifiability. Journal of Risk and Uncertainty 26, 5-16

Sunstein, Cass R. (2003) Terrorism and probability neglect. Journal of Risk and Uncertainty 26, 121-136

Sutton, Malcolm (1994) Bear in Mind these Dead .... An Index of Deaths from the Conflict in Ireland 19691993. Belfast: Beyond the Pale Publications

Tsiddon, Daniel (1995) On the macroeconomics of defense expenditures. Mimeo, Jerusalem: Hebrew University

US Department of State (various years) Patterns of Global Terrorism. Washington, DC: US Department of State

Van Praag, Bernard M. S. and Baarsma, Barbara E. (2005) Using happiness surveys to value intangibles: The case of airport noise. Economic Journal 115, 224-246

Viscusi, W. Kip and Zeckhauser, Richard J. (2003) Sacrificing civil liberties to reduce terrorism risks. Journal of Risk and Uncertainty 26, 99-120

Walkenhorst, Peter and Dihel, Nora (2002) Trade impacts of the terrorist attacks of 11 September 2001: A quantitative assessment. Paper prepared for the workshop on the Economic Consequences of Global Terrorism, Berlin, June 14 - 15, 2002

Welsch, Heinz (2002) Preferences over prosperity and pollution: Environmental valuation based on happiness surveys. Kyklos 55, 473-494

Wildasin, David E. (2002) Local public finance in the aftermath of September 11. Journal of Urban Economics 51, 225-237

Wilkinson, Paul (2000) Terrorism Versus Democracy: The Liberal State Response. London and Portland, OR: Frank Cass

Zeckhauser, Richard J. and Fisher, Anthony C. (1976) Averting behavior and external diseconomies. Kennedy School Discussion Paper No. 41D, Harvard University 